Dušan Jerotijević ${ }^{1}$

University Union "Nikola Tesla" Belgrade

Business and Law Faculty
SCIENTIFIC REVIEW ARTICLE

DOI:10.5937/ekonomika1704105J

Received August, 01, 2017

Accepted: November, 30, 2017

\title{
AGAINST LEGAL SECRESSION OF ALBANIAN MINORS IN SERBIAN AUTONOMOUS KOSOVO AND METOHIJA AND ECONOMIC IMPLISATIONS
}

\begin{abstract}
National minorities in Yugoslavia after the Second World War experience different treatments. The German minority was almost completely evicted for participating in the war on the side of Nazi Germany. On the other hand, the Siptar minority (later Albanian) is expanding its living space to the expense of the Serbian people, which, even by legal acts, forbids return to the area from which Serbs were expelled in World War II. Albanians are given absolute authority on the territory of AP Kosovo and Metohija. At the same time, large numbers of Albanians from Albania are allowed to enter this region. Throughout the period since the end of the Second World War, the disappearance of Serbs from Kosovo and Metohija and some other areas where the Albanians were numerous has continued to this day. The constitutional legal development of the SFRY from 1946 to 1974 sets the legal basis for the break-up of Serbia. The last act of de facto separation of Kosovo and Metohija from Serbia was NATO aggression in 1999.
\end{abstract}

Key words: national minorities, Kosovo and Metohija, Albanians, Serbia, NATO

JEL Classification:

\section{ПРОТИВПРАВНА СЕЦЕСИЈА АЛБАНСКЕ МАҢИНЕ У СРПСКОЈ АУТОНОМНОЈ ПОКРАЈНИ КОСОВО И МЕТОХИЈА И ЕКОНОМСКЕ ИМЛИКАЦИЈЕ}

\begin{abstract}
Апстракт
Националне мањине у Југославији после Другог светског рата доживљавају различите третмане. Немачка мањина је била скоро у потпуности исељена због учешћа у рату на страни нацистичке Немачке. Са друге стране шиптарска мањина (касније албанска) иири свој животни простор на рачун, пре свега српског народа, коме се чак правним актима забрањује повратак у области одакле су Срби протерани у Другом светском рату. Албанцима се даје апсолутна власт на територији АП Косово и Метохија. Истовремено се дозвољава велико досељавање Албанаца из Албаније у ову покрајину. У читавом периоду од краја Другог светског рата до данашьег дана траје исељавање Срба са Косова и Метохије и још неких области где су Албанци
\end{abstract}

\footnotetext{
$\underline{1}$ dusanjerotijevic@gmail.com.
} 
били бројни. Уставноправни развој СФРЈ од 1946. године до 1974. године поставља правни темељ за разбијање Србије. Последњи чин фактичког одвајана Косова и Метохије од Србије била је НАТО агресија 1999. године.

Кључне речи: националне манине, Косово и Метохија, Албанции, Србија, HATO

\section{Introduction}

The nationalist separatism of the Kosmet Albanians in the time of the Tito's government since 1945, to this day, was heading towards the creation of a new state on the ground already existing. It was manifested in various forms and types depending on the level of social, political and economic compactness and stability of Serbia, as well as its position in international, and especially European relations and relations.

The escalation of the violence of Albanian extremists and their alliance with NATO during the 1999 bombing of the FRY opened the way for the most serious destruction of the security of the Republic of Serbia. Its citizens are threatened by basic human rights and freedoms that are reflected in human casualties and material destruction. At the same time, there are prevalent estimates that this violence will represent the most serious form of threat to Serbia's security in the future, but that as a socio-historical phenomenon it will be an inevitable follower of the entire social community.

We need to say something about the name Albanians used only in the second half of the 20th century. Namely, the Albanians use the name Śćipetar for themselves today, which is also used in Serbs (Siptar) in a somewhat changed form for centuries. The term Albanian is derived from the name of the state, so it began to be used as a preparation for the creation of the state of "Great Albania". It should be remembered that in the time of the Turkish authorities, especially since the 18th century, intensive settlement of Albanians in the original Serbian territories in the area of Old Serbia (Kosovo and Metohija, today's northern Albania and the Vardar region) were carried out. This trend continued from 1941 until the present day, when hundreds of thousands of Albanians were settled by Kosovo and Metohija, with the simultaneous emigration of hundreds of thousands of Serbs.

\section{The term is entitled to self-determination}

In the period before the First World War, the notion of the right of people to selfdetermination was born. It was the right of one's own state within the country in which the members of a particular national group live.

Although the origin of expression self-determination, that is, the right to selfdetermination, dates back to the middle of the nineteenth century, it is not possible to determine in which language exactly this term was expressed for the first time.

In the memorandums of Czech deputies from 1870, it is mentioned that all peoples have the right to self-determination, whether they are large or small. The German term of the notion of the right to self-determination appears in 1865. Since the end of the 
19th century, both the Austrian and Russian socialists, wishing to break the power of the ruling groups, were very much in favor of developing the concept of self-determination. They considered that self-determination was the individual right of every individual to maintain a cultural identity and that he in some way carried with him his cultural affiliation with the particular nation, although he was far from the region in which his nationality was the majority.

The Bolsheviks were in a different position; they considered that the right to self-determination was a collective right, that is, the right of the people in their own independent territory and the right of the people to sovereignty provided that they make the majority in the territory concerned. In a desire to suppress the czarist politics and create the republic publicly proclaimed that all nations belonging to Russia must be recognized the right to secession and the creation of their own state. The taking to the point that without any subordination, and in a democratic way, all the nations agreed to remain connected to such a republic with their own desire. Supporting every request of a particular nation to free secession should be considered on a case-by-case basis and always in line with the interest of the overall social development. The Bolsheviks considered the right to self-determination the universal right of all, even the colonial peoples. The Bolshevik conception was directed primarily against the interests of the Russian people and the Russian state. This is best seen through the development of the USSR from 1922 until its disintegration in 1991. During this period, the Russian nation was broken into several nations, and the territory of Russia was reduced by millions of square kilometers.

The right to self-determination in Lenin was used exclusively as an instrument of struggle against the existing state order, and only later it was transferred to the foreign policy area through the request for the freedom of the colonized peoples. In the Americans, the right to self-determination was called the right to independence and liberation from colonial, overseas European powers. President Wilson exclusively exercised the right to self-determination for the purpose of dealing with an external opponent. We can conclude on these examples that there are different understandings and origin of the claim for the right to self-determination.

\section{Self-determination in terms of self-government, not in terms of changing the territorial order}

The United States was not a multi-national state in the European sense and did not have problems with the different peoples living around the borders of states, as was the case in Europe (Fiš, 2013, p. 148). In Europe, it was about creating new states based on the right to self-determination. Self-determination, which does not mean a mere change in state relations, but only non-colonization, is considered legitimate while the illegitimate (secessionist) changes are known and also represent "two sides of the same medal". The need to establish a clear boundary of the right to self-determination has been increasing as well as the dangers that exist depending on what idea these peoples adopt. 


\section{The right of the winner and the right to self-determination}

Countries that emerged during the First World War were subject to the law of war in which the right of the winner was valid. However, at the end of the war, the idea of the right to self-determination and the desire of the population living in a particular territory enter the scene (Fiš, 2013, p. 148). It is necessary for the inhabitants of certain areas of the winning state to become part of a victorious state in order not to enter into conflict with each other. This is justified by the fact that everyone calls for different principles: won the right to self-determination and winners to the right of the winner.

An example of a territorial dispute brought before the League of Nations clearly shows the validity of the law before the end of the war (Fiš, 2013, p. 154-155). For example, the Aland Islands belonged to Finland to the secession of this country from Russia, and as part of imperial Russia. In an informal interview, the population expressed a desire to join Sweden, while Finland sought these islands for themselves. Expert opinions were such that international law does not recognize the right to self-determination and therefore the right to secession. The islands of Aland remain in Finland, although the local population predominantly spoke Swedish. Referring to the "right of the people to freely determine their fate" as Wilson was then speaking about, the demand of the inhabitants of the Atlantic Islands was clearly rejected, with the obligation of Finland to recognize autonomy for these islands.

\section{The right to self-determination as a human right}

The United Nations has made a declaration on human rights as well as human rights pacts in which the right to self-determination is proclaimed human rights. Initially, it is understood as an individual right, the right of every person to choose the country in which he wants to live, while understood as a collective right means that the population of a fortified territory has the right to determine his or her nationality, or that a group of people is related by origin, in a common language, Territorial principle is entitled to own state (Fiš, 2013, p. 148).

In the years that followed the central government, the state weakened, and demands for self-determination increased, primarily in Yugoslavia, which was organized as a federation. The separation of Montenegro from a reduced Yugoslavia through a referendum was marked by the breakup of the federation. In addition, there is a continuation of conflicts within the republic between Albanians and Serbs in Kosovo and Metohija (areas not controlled by the central government in Serbia) and further deterioration of the situation of the Serbian population. The right to secession does not have a lower administrative unit but only members of the first order, that is, the entities. Similarly, the right to secession has no Albanians from the area of the Serbian autonomous province of Kosovo and Metohija. All the opposite would lead to the indefinite fragmentation of one territory, leaving the state to lose any stability.

Conflicts between different groups cannot be solved only by the division of the territory, but there must be other compromise solutions. Who starts from the subjective criteria for secession must agree on the independence of Kosovo. The one who adheres to a clear formal, objective criterion must firmly reject the independence of this area 
(Fiš, 2013, p. 245-254). Since the criteria are mixed, there is a lot of damage, lack of consistency and regularity. Regardless of the expressed will of the population and the homogeneous character of Kosovo and Metohija, one cannot indulge in the further dismemberment of the Republic of Serbia and its constituent parts.

\section{Who can be subject to the right to self-determination?}

The state does not only constitute a territory, but also a population that must be a state-making nation identical with the territory of the territory it encompasses. The problem exists when there is no such match and therefore there is no right to create a sovereign state. Self-determination is a compensation for the suffering suffered. If the superior authority acts in accordance with its obligations and duties, then the subordinates must comply with their obligations.

The airborne NATO bombardment and the threat of land invasion forced the FR of Yugoslavia and Serbia to leave their province Kosovo and Metohija with their army. All this at order to support the secessionist movement of the Kosovo in Albania. Its subfederal unit within Serbia, formed as the Autonomous Province of Kosovo and Metohija, was given an Albanian minority. In the 1974 Constitution of the SFRY, almost all state powers were transferred to its provinces and republics.

Every republic and province within Yugoslavia had the right to vote within the collective state representation. The federal government retained the only right over the Yugoslav federal army (however, in 1969, another form of armed forces, an easily armed territorial defense, was created to allegedly prevent a possible Soviet invasion). The communist authorities were unable to stop the spread of the secessionist movement among the Albanian population. The Kosovo-Serb anti-separatist movement launched a campaign of public protests and demonstrations in Belgrade for the defense of Serbs from Kosovo. Demonstrations by Kosovo Albanians in 1981 against Serbian rule over the province demanded the secession of this province from Serbia. Responding to the draft of a new constitution of Serbia in which political autonomy is withdrawn, Kosovo MPs, without their non-Albanian counterparts, proclaim in July 1990 the sovereignty of the Republic of Kosovo and its secession from Serbia. However, the European Community and other countries refused to recognize it. The main secessionist party, the Democratic League of Kosovo, organized an Albanian leadership structure that was tacitly tolerated by the Serbian authorities in Kosovo and Metohija.

The Illegal secessionist group of the Kosovo Liberation Army (KLA) launched a series of murders and bombings on Serbs as well as Albanian members of the Serbian authorities. In 1998, a mass uprising against the authorities of the Republic of Serbia and the FRY began. By the end of the year, the armed forces of the FRY managed to force the KLA to retreat into the mountains and there was a ceasefire overseen by the Organization for Security and Cooperation in Europe (OSCE), which enabled the KLA to recover some of its lost territory.

As the Milosevic regime refused to have its forces in Kosovo and Metohija numerically equitably represented by the UN forces (NATO forces), NATO started the bargaining of Serbia and Montenegro in March 1999 and in June 1999 (after the signing of the Kumanovo Agreement), the army The FRY is forced to leave Kosovo and 
Metohija. There have been the return of 700,000 Albanian refugees, and over 250,000 Serbs and non-Albanian people have fled to the central parts of Serbia. Under the resolution 1244 Kosovo and Metohija became a protectorate of the United Nations with NATO-led peacekeepers. The NATO military intervention enabled the de facto secession of Kosovo and Metohija from Serbia (Pavković and Radan, 2008, p. 231-231). In this way, the use of force in international relations has come to full expression, ignoring the norms of international law (Jerotijević and Palević, 2016, p. 142).

\section{Equality of all groups within the federal state system}

The secessionist group is in almost all cases a national minority that wants to establish a state that will express its national identity. The question arises whether ethnic cleavages that seriously endanger the ethnic or national identity of groups outside secessionist states should be internationally recognized. Prior to secession, Serbs from Kosovo and Metohija fled a great deal, showing that they felt seriously threatened with this secession. If there is a suspicion that they would be endangered by this secession, international recognition of such secession should not be exercised as long as the last suspicion regarding the seriousness of the threats is not remedied.

If Serbs and other minorities (numerically minorities) are expelled, the secession of Kosovo and Metohija should not be recognized because secessionists are not able to prevent damage or to avoid damage that can cause their secession (Pavković and Radan, 2008, p. 321-323).

One of the main features of national minorities is loyalty to the country of origin, while secessionists in Kosovo almost always represented the state in which they live as hostile and alien forces. Secessionist groups to gain support for their secessionist project declared opponents of secession as treacherous national assets and prevented them from publishing their arguments against secession in public.

\section{Violation of human rights as secessionist propaganda in Kosovo}

Immediately before the breakdown of the secessionist clash, the country's State of charge for genocide and systemic human rights violations occurred, which was not the case in the original complaints of the Kosovo Albanians in 1981. This leads us to conclude that attempts at secession have not been done only to eliminate the injustice done, but that the secessionist leaders in Kosovo through their movements using the armed forces have received a useful means of gaining international recognition. Why is it necessary to use force to achieve morally worthwhile goals (just as human rights are justified)?

If the State of origin allows for the realization of human rights, it does not expose them to discrimination, allows them to be present in political life, enables them to use their mother tongue, potential secessionists who are most often a national minority within the state, have no reason to create a new, own state that respects their human rights. One of the basic rights of national minorities is the right to use the language of the national minority (mother tongue) that was guaranteed by the Constitution of the 
FRY and the Constitution of the RS. According to the law on the election of deputies, the participation of representatives of a national minority in the parliamentary life of Serbia is guaranteed if the electoral list receives at least $5 \%$ of the total number of votes. The right to education in the language of minorities was also enshrined in the Constitution of the FRY and the Constitution of the Republic of Slovenia. The Laws on Primary and Secondary School enable the conduct of bilingual teaching. According to Article 46 of the FRY Constitution, members of national minorities have the right to public information in their own language (Helsinki Committee for Human Rights in Serbia, 2002, p. 20-22).

In 1964, Albanians were recognized as a national group, and their language was given the status of one of the official languages in Yugoslavia, which would mean that the Albanians gained the right to study in their mother language. By creating Tito's Yugoslavia, Albanians in Kosovo gain a very wide autonomy. It is also a fact that such autonomy exceeded all world standards and de facto signified an independent state of Kosovo.

Based on the examination of the situation after 1945, it can be argued that the Albanians never wanted autonomy but only the ability to secede from Serbia and to annex parts of Macedonia, Montenegro and Central Serbia, so that they together became part of Great Albania.

In the post-war period, the federal government was trying to improve the social and cultural life of Albanians in Kosovo, published in Albanian language, created cultural and artistic societies, opened theaters. Albanian women, traditionally subordinated patriarchs, were given the opportunity to study and make choices for themselves in a better position in society. Albanians received scholarships for all levels of education, including most. By the 1963 constitution, the term "national minority" is deleted and replaced with the word "nationality", thus bringing Kosovo status to a higher level. Through constitutional amendments adopted in 1968, the degree of autonomy has been increased, and the province itself gets a constitution. Legislative and judicial authorities are also being transposed. In the Presidency, as the supreme federal body, the representative of Kosovo was also sitting on an equal footing with the other representatives of all six republics.

Under the 1974 Constitution, the autonomous provinces had the right to propose laws at the federal level, as well as the veto power of any decision they deemed to endanger their vital interests. The only difference was that the republics were guaranteed the right to self-determination to secession, and the provinces did not, because it was considered that the increased degree of political, cultural and economic independence was sufficient to satisfy even the most extreme demands for autonomy. However, the aggressive nationalist tendencies have led to the tacitly illegal operation of many separatist organizations, street demonstrations, and open confrontations with the authorities. Textbooks in the Albanian language were imported from Tirana, listened to the Albanian radio and watched television in the Albanian language. This has greatly increased the indoctrination of Albanians to anti-Serb propaganda. During the recruitment, the Albanians had the advantage, the Albanians were district judges in the district courts, and the rights of the Albanians overwhelmingly exceeded the rights of Serbs in Kosovo and Metohija.

The Albanians had a University in Pristina that enjoyed full autonomy in their native language. It was the University of Pristina that was a nursery of Albanian nationalist unrest. 
The first "peaceful" protests were soon organized not from the desire to improve living conditions, food and housing, but to highlight the clear demands of the "Kosovo Republic". In 1981, Serbian and Montenegrin companies were looted and destroyed, and a mysterious fire set fire to one wing of the Pećka Patriarchate. On this occasion, the Albanian judge stated that the fire was not planted but was caused by a failure on the installations. The riots also spread to western Macedonia where they urged members of the Albanian minority to rise. The next year, they change strategy. They no longer organize protests within Kosovo and Metohija but are already engaged in the organization of kidnappings of Yugoslav representatives abroad, illegally working in Western Europe, smuggling gold, drugs and weapons and financed by these separatist groups.

By providing such foreign support and accusing the Serbs of oppression, they even found support in the Western media back in the 1980s. Even US senators lobbied for them. A very quick "Kosovo thing" is declared a fair fight and is increasingly gaining support in prominent public figures. Empowered by constitutional rights granted to them by the 1974 constitution with a special veto on any republican decision, life for Serbs who lived in Kosovo at that time becomes unbearable. At that time, some $30 \%$ of the total population of the province was Serbs. Abused and subjected to strong pressure to move from Kosovo, that number fell to $20 \%$ during the 1970 s, dropped to $14 \%$ in the 1980 s, and in the 1990s dropped to $10 \%$. On the other hand, the Albanian population is doubling and in the 90's they account for $90 \%$ of the population of Kosovo. Nevertheless, these numbers should be taken with delays in terms of manipulation during the census by the Albanian authorities in this province. This is a unique phenomenon in one country that parts of the supporting nation are fleeing from their territory under the pressure of the national minority.

The International Helsinki Federation for Human Rights warns of the fact that Serbs are fleeing from Kosovo and Metohija because of intimidation and threats, pressure and violence and other serious human rights violations, and only because of ethnicity. The Serbs could not turn to the institutions of the system for protection because Albanians occupied the most important positions in the Coumunitation, Police, Judiciary and State Administration. There was a cultural and linguistic discrimination against them, schools in the Serbian language were closed, Serb cultural monuments were destroyed, and violence against the Serbian Orthodox Church and its property was highly accentuated. Serbs from Kosovo and Metohija are organizing protests to inform the Serbian public about the difficult situation of the remaining Serbs in Kosovo and Metohija. Many times the Serbs were prevented from coming to Belgrade and demonstrating because the federal police, fearing that this would turn into a wider Serb nationalist movement, were always scattered.

The problem of endangering the stability and integrity of the entire state was realized because of the increasingly open manifestation of chauvinism by the Albanian leadership.

Constitutional amendments from 1989 enabled Serbia to regain competencies in the area of national defense, judiciary and finance, and social planning. In all other areas regarding the right to use mother language, the right to culture, education, as well as autonomous rights in the field of economy and local self-government, the Albanian minority enjoyed a very wide autonomy. All this was done under the strong pressure of the International Monetary Fund for the purpose of economic liberalization. 
The international community has used this to condemn these changes and paste the label to Serbia as oppressive for the Albanians, and publicly declares the Serbian government to violate the human rights of Albanians. Shortly thereafter, the denial of international financial assistance, as well as any kind of economic aid, only further encouraged the Albanian separatists to become even more severe in their demands for the proclamation of their own republic. For these reasons they did not ask for a solution within the Republic of Serbia. They boycotted the elections and did not want to take legal action by using their right to vote, and then through their deputies in the Serbian parliament, to participate in the work of Serbian political institutions. Instead, they were elected in an illegal election by a parliament that never functioned and elected Ibrahim Rugova as its prime minister, which in no way contributed to the introduction of democracy into political life.

In the Dayton Agreement, the return of autonomy and the issue of Kosovo's human rights in the framework of Serbia was an unacceptable solution for the Albanian separatists. Soon, the terrorist actions were intensified by the Albanian guerrilla, which in the media of the West; these criminal attacks are barely mentioned. The increasing pressure from the US Department of State, such as the prerequisites for removing the sanctions of the FRY, was exposed to the authorities in Belgrade in order to solve the Kosovo problem and made more and more concessions to the Albanians.

Serbia had to start antiterrorist action, as Serb policemen were killed from the ambush and kidnapped. Threats were directed to all Serbs and Albanians loyal to Serbia (who were considered traitors). The United States claims that Kosovo and Metohija should remain part of Serbia, while at the same time it continues to put pressure on the Serbian government and threatens to bomb NATO forces. While consciously admitting that both Serb and Albanian forces are involved in the conflict, only the ultimatum is sent to Serbia, and only the Serbian side is accused of the conflict.

According to the Holbrooke-Milosevic agreement, Serbian forces would withdraw from Kosovo until the Albanian forces and the KLA, if they violate the agreements reached in the agreement, can go unpunished. With the presence of the OSCE monitoring mission, KLA leaders renewed their guerrilla actions and carried out criminal actions against Serbs. Without any investigation carried out, the OSCE observing group accuses the FRY of having committed a massacre in Račak, although many European journalists described it as an installation. This was the reason that the occupation of NATO in Kosovo and Metohija was legitimately accepted.

The Serbs in Rambouilletwere ready to consider the deployment of international forces in Kosovo with the only condition that they should not be commanded by NATO forces, but by the UN or the OSCE, as organizations of a non-military character. Otherwise, there would be a threat to national sovereignty and territorial integrity. NATO forces would be completely exempted from immunity from the agreement by the agreement, without using the infrastructure of the entire state, would cross its territory completely unhindered with the conduct of training and operational activities, which would mean a renunciation of their own sovereignty over their own country. For a part of the international community, this was a sufficient reason to make a decision on the military intervention of NATO forces on the bombing of Yugoslavia on March 24, 1999 (Vlajki, 2007, p. 50-56). 


\section{Marginalization of traditional international institutions}

To what extent can international relations be transformed into the international community? It seems that legal law has become a reliance on the use of force. It even looked favorably at the use of force and violence, although there is a general ban on the use of force formulated in Article 2 (4) of the UN Charter and constitutes a crime against peace. According to this article, not only states, but also every international entity, which has legal personality, refrain from using force.

Violation of territorial sovereignty cannot be acquired as a legal right in the territory. The Republic of Serbia shares its sovereignty with its provinces, which are not states, nor are they based on the sovereignty of the people. She as such is not any different from other republics. Constitutional-legal solutions in the provincial-state relations were also largely concerned with the republicanization of the province, which in particular did not support the provision of the necessary statehood measure in the province. The responsibility of the then government and the constitutional courts also denied it, and they were more appropriately crumble up with some separately concluded agreements such as, for example, was an agreement on education and cultural cooperation with Albania in 1985.

The expulsion of the province independently on the international plane is also only one of many forms of violation of international law, as well as putting only the province's name in that traffic with the world to which the constitutional courts remained silent.

In order to preserve the borders of its state, it was necessary to reduce the level of statehood that the province had as such, in order to provide the Serb people and minorities living in it sovereignty (Vuković, 1985, p. 99-105).

Kosovo and Metohijacontinue to impose a legal uncertainty - now in the process of stabilizing and joining Serbia to the European Union. The European Union, through a number of unilateral acts of recognition of an independent state, came to the position of the EU member states, due to certain political goals, to challenge its internal (European) law, as well as the Serbian Constitution as a partner country.

The Union has thus greatly contributed to the creation of a single precedent in European and world relations, according to which unilateral secession from the territory of a sovereign and internationally recognized state is a legitimate act for the EU and its members. Especially, because this did not happened to accordance with International Law and UN Security Council Resolution 1244 (Samardžić, 2009, p. 194). The proclamation and recognition operation followed without any decision or recommendation of the UN bodies that assumed international responsibility for the situation in Kosovo and Metohija, but they originated from an internationally informal and UN Security Council unsuccessful proposal, the so- Kosovo's supervised independence.

In international relations, Kosovo and Metohija is a precedent, which means a case that stems from the rule. Solving the case by the rules inevitably leads to violence that is an example that can be repeated once again in similar situations in an uncontrolled manner.

The European Union should reconcile the state's right to territorial integrity and the right of territorially concentrated minorities to its own self-government and to derive a solution for Kosovo-Metohija issues (Samardžić, 2009, p. 197-198). Otherwise, in the absence of democratic institutions and the backward economy, Kosovo and Metohija is easily becoming a cause for political manipulation. 
Instead, the EU chose the previous political argument that Kosovo (the name used by the states recognized by it and the separatist authorities in Kosovo and Metohija) has fallen economically because it is not independently supported by material tangible arguments and is at the donor conference organized by the Helped with 1.6 billion euros given from individual member states, instead of providing an economic environment that would be able to secure sustainable economic development and exit from the economic crisis (Samardžić, 2009, p. 198-208).

Brussels could have established an internal (constitutional) relationship that would allow the province a full autonomy to the economy, which would not be burdened with the question of sovereign superiority and subordination. All of their special rights can be achieved by a certain group of people (ethnic and cultural) through specific, constitutionally defined and protected norms and institutions without causing damage to the country whose part of the territory should be seceded.

The right to self-determination cannot be enjoyed by national minorities within the existing states, and that right is only a principled possibility for the people in question to establish their own state under the strict condition that it is not a secession of the territory of an existing state.

It is necessary to continue to seek clear conflicting solutions and a specific arrangement that will really be in line with conflict resolutions in the territory of Kosovo and Metohija, which does not necessarily have to be the Republic of Kosovo.

\section{Conclusion}

The prerequisite on any solution to the Kosovo issue, which is at the moment a Serbian issue, is all full of truth about Kosovo and Metohija, without any embellishment and political manipulation. The question arises and why the people have been silenced about the violence, occupation, pressure, persecutions and usurpation of the rights of Serbs from Kosovo and Metohija. This cannot be legalized. After learning the truth, it is necessary to establish full justice and guarantees of the freedom and peaceful life of all in Kosovo and Metohija.

The issue of Kosovo and Metohija has not been completed for the Serbian people. With the issue of redundancy of the state border and the terrible injustice that has been done, neither the Serbian state nor the Serbian people can be reconciled. We must trust the international law, which is currently being abolished, and independent international institutions, as the last defense of the disrupted world order, that it will not bypass the case of Kosovo and Metohija.

The future of Kosovo and Metohija is where it's past, in Serbia.

\section{References}

Đorđević, Ž.(1997)GubicistanovništvaJugoslavijeuDrugomsvetskomratu, ABCGRAFIKA, Beograd.

Đorđević, Ž. (2004)IstinomzaSrbiju, Gambit, Jagodina. 
Đorđević, Ž. (2009)KosovoiMetohijakrozvekove, Gambit, Jagodina.

Đorđević, Ž.(2012)SatiranjesrpstvauXIX iHHveku, DraslarPartner, Beograd.

Đorđević, Ž.(2014)UlogaVatikanaiEngleskeusatiranjusrpstva, DraslarPartner, Beograd.

Fiš, J. (2013) Pravonarodanasamoopredeljenje, AlbatrosPlus, Beograd.

GenocidnadSrbimanaKosmetu (1945-1990), https://www.stormfront.org/forum/ t432366/.

HelsinškiodborzaljudskapravauSrbiji (2002) Nacionalnemanjineipravo, Beograd.

Jerotijević, Z. and Palević, M. (2016) The balance of power - The security concept of the international community, učasopis: Ekonomika, br. 1, Društvoekonomista „Ekonomika“, Niš.

Kaseze, A. (2011) Samoodređenjenaroda, Službeniglasnik, Beograd.

MitropolitAmfilohije(2011)ČasnikrstHristovikosovskizavjet, Svetigora, Cetinje.

MitropolitAmfilohije (2011)KosovojeglavaLazareva, Svetigora, Cetinje.

MitropolitAmfilohije(2011)Ljetopisnovogkosovskograspeća-dnevničkizapisimartavgust 1999., Svetigora, Cetinje.

Mitropolit Amfilohije (2011) Ljetopis novog kosovskog raspeća - dnevnički zapisi septembar 1999 - decembar 2000., Svetigora, Cetinje.

Nadoveza, B.(2008)IstorijabalkanskihnarodaXIX i XXveka, SRS, Beograd.

Pavković, A. andRadan, P. (2008) Stvaranjenovihdržava, Teorijaipraksaotcepljenja, Službeniglasnik, Beograd.

Petrović, R.(1990)ZaveraprotivSrba, Dositej,Beograd.

PolitičkonasiljenaKosovuiMetohijiod 1945. do 2003. godine,http://nardus.mpn.gov. rs/handle/123456789/3075 ?locale-attribute $=$ sr_RS.

Samardžić, S. (2009) SrbijauprocesupridruživanjaEU, Službeniglasnik, Beograd.

Vlajki, E. (2007) KosovskoraspećeSrbije, NikolaPašić, Beograd.

Vuković, I. (1985) AutonomaštvoiseparatizamnaKosovu, Novaknjiga, Beograd. 